\title{
Peptic ulcer in Assam
}

\author{
S. L. MALHOTRA, C. T. MAJUMDAR, AND P. C. BARDOLOI \\ From the Medical Department of the North-east Frontier Railway, \\ Kamrup, Assam, India
}

EDITORIAL SYNOPSIS Big differences in the prevalence of peptic ulcer are known to exist in different parts of India. This paper reports a high incidence in Assam and records certain differences with peptic ulcers found in south India.

Peptic ulcer in India has a peculiar distribution. It is reported to be very common in south India and rare in the Punjab. It is also believed to be different from the disease in the West in being less acute and less likely to bleed or perforate (Dogra, 1940; Somervell and Orr, 1936; Hadley, 1959; and Raghvachari, 1959). The study reported in this paper was undertaken to determine the incidence and behaviour of ulcer in Assam.

Assam is the extreme north eastern region of India and is noted for its extreme humidity. The annual rainfall ranges from 70 to 140 inches, mean minimum temperature is $40.6^{\circ} \mathrm{F}$, the mean maximum temperature is $99 \cdot 5^{\circ} \mathrm{F}$. the relative humidity is $86 \%$ (Lumding figures) and the height above sea level is 182 to 348 feet. The pace of life is unhurried even in big towns. Houses are made of bamboo matting with or without plaster and with roofs made of elephant grass. Only lately masonry buildings have come into existence.

This study is confined to railway workers and their families who live and work in Assam.

\section{MATERIAL AND METHODS}

Diagnosis was based on clinical symptoms and signs, the presence of complications, and barium meal studies. No gastroscopic studies were undertaken. In 50 patients at Gauhati, gastrectomy was done which also confirmed the presence of ulcer. The clinical data are derived from the case records of all the ulcer patients, numbering 452 , admitted to the railway hospitals at Gauhati, Lumding, Dibrugarh, and Alipurduar during 1959 and 1960. Patients treated as out-patients have not been included because of the serious disadvantage of the out-patients' records occasionally being less precise and complete and of varying competence. Data on perforation were expecially studied as perforation of an ulcer is usually a particularly painful and serious disease and expedites hospital admission in all in whom it develops. The incidence of perforation, therefore, would give an index to the incidence of ulcer.
To get a more realistic picture of the incidence of ulcer, a survey of railway staff was undertaken at the head office of the railway at Gauhati and at the locomotive repair shop at Dibrugarh. Every person at work was individually interviewed to find those who gave a history of an ulcer-like pain, indigestion, night pain, malaena, haematemesis, perforation, or a known diagnosis of ulcer. The survey at Dibrugarh was carried out by one of us (P.C.B.) and the other at Gauhati by C.T.M., under the direction of the principal author. The survey at Dibrugarh covered all workers, whether at work or absent, whereas the survey at Gauhati, due to an initial mistake in planning, covered only those who were at work at the time of the interview. It is possible that there may have been cases of peptic ulcer amongst the absentees in the Gauhati group.

Railway employees have to obtain a medical certificate in case of absence due to illness. These certificates for Lumding and Gauhati have also been studied to find out the number of railway servants who were absent from work in 1960 with a diagnosis of peptic ulcer.

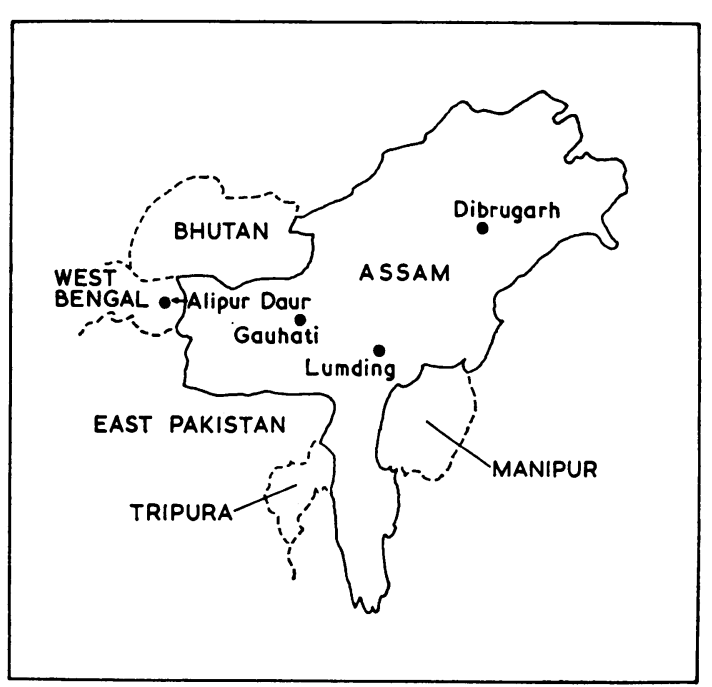




\section{RESULTS}

HOSPITAL CLINICAL RECORDS In Table I are presented the number of ulcer patients and the total number of patients admitted to hospital during 1959 and 1960 in the four railway hospitals. The admissions for ulcer expressed as a percentage of all admissions were $4.1 \%$ for Gauhati, $2.7 \%$ for Lumding, $4.3 \%$ for Dibrugarh, and $2.8 \%$ for Alipurduar. The railway population (adult employees) in these cities is precisely known and the incidence of patients with acute ulcer requiring admission works out to $2 \cdot 13 \%$ for Gauhati, $1.75 \%$ for Lumding, and $1.2 \%$ for Dibrugarh each year.

At Lumding the railway colony is compact and the railway hospital is the only medical institution in the area. All patients must, therefore, come to the railway hospital. In the case of Lumding, we have also collected the number of patients treated as out-patients. There was a total of 351 ulcer patients at Lumding in 1960 and the incidence of active ulcers in the employees works out to $5.3 \%$ in the age group 18 to 55 years (employees only) and an incidence of $1.3 \%$ in the population of all ages, i.e., employees as well as their families.

The disease was 10 times more common in males than in females and the highest incidence was in the age group 21 to 30 years $(44.2 \%)$, the incidence being low under 20 years and over 50 years(Table II).

An analysis of signs and symptoms was made in the 233 patients, i.e., the 1960 admissions to the four hospitals included in this study (Table III).

Pain was present in only $84 \%$ of the patients. A history of melaena was present in $30.5 \%$ of our cases. There were several patients in our study both in the hospital series as well as in the survey group in whom the presenting and the only symptom was melaena, sometimes massive, without any pain or indigestion. We have carefully gone into their histories and have found a characteristic periodicity in this symptom also.

Table IV gives the age and sex distribution of the 101 patients with haemorrhage-melaena or haematemesis; males in the age group 21 to 40 years
TABLE II

AGE AND SEX DISTRIBUTION (1960 FIGURES FOR GAUHATI, LUMDING, AND DIBRUGARH HOSPITALS)

\begin{tabular}{lll} 
Age in Years $\quad$ Male Female & $\begin{array}{l}\text { Percentage of } \\
\text { Total }\end{array}$ \\
\hline
\end{tabular}

\begin{tabular}{lrrr}
\hline Below 20 & 1 & 1 & 1 \\
$21-30$ & 89 & 14 & 44 \\
$31-40$ & 79 & 3 & 35 \\
$41-50$ & 37 & 3 & 17 \\
Above 50 & 6 & 0 & 3
\end{tabular}

TABLE III

ANALYSIS OF SIGNS AND SYMPTOMS IN 233 PATIENTS

\begin{tabular}{lcc} 
Symptom & No. of Patients & $\begin{array}{l}\text { Percentage of } \\
\text { Total No. of } \\
\text { In-patients }\end{array}$ \\
\hline Pain & 196 & 84 \\
Loss of weight & 41 & 18 \\
Vomiting & 78 & 33 \\
Haematemesis & 36 & 15 \\
Melaena & 71 & 30 \\
Periodicity & 160 & 69 \\
Heart burn or acidity & 83 & 36 \\
Loss of appetite & 29 & 12 \\
Constipation & 43 & 18 \\
Anaemia & 32 & 13 \\
Perforation & 19 & 8 \\
Visible peristalsis & 10 & 4 \\
Epigastric tenderness & 59 & 25
\end{tabular}

predominate, the complication being 19 times more common in men than in women. Our worst and the youngest patient, however, was a girl of 14 years of age who was admitted with a sudden massive and severe haemorrhage without any previous history.

There were 19 patients admitted for perforation: five at Gauhati, eight at Lumding, five at Alipurduar, and one at Dibrugarh, the overall admission rate for perforation being $8.1 \%$ of ulcer admissions.

Vomiting was present in one-third of our patients and in nearly half of them it was self-induced to get relief from pain or distension. The usual method employed was tickling the back of the throat with the fingers. Visible peristalsis was observed in 10 patients $(4.3 \%)$; seven patients $(3 \%)$ had organic

TABLE I

NUMBER OF ADMISSIONS IN THE FOUR RAILWAY HOSPITALS FOR THE TWO-YEAR PERIOD 1959-60

\begin{tabular}{|c|c|c|c|c|c|}
\hline Hospital & $\begin{array}{l}\text { Mean Relative } \\
\text { Humidity Annual } \\
\text { Total }(\%)\end{array}$ & Employees Served & $\begin{array}{l}\text { Total In-patient } \\
\text { Admissions for All } \\
\text { Diseases }\end{array}$ & $\begin{array}{l}\text { No. of Peptic Ulcer } \\
\text { Cases }\end{array}$ & $\begin{array}{l}\text { Percentage of Total } \\
\text { Admissions }\end{array}$ \\
\hline $\begin{array}{ll}1 & \text { Gauhati } \\
2 & \text { Lumding } \\
3 & \text { Dibrugarh } \\
4 & \text { Alipurduar } \\
& \text { (West Bengal) }\end{array}$ & $\begin{array}{l}84 \\
86 \\
88 \\
85\end{array}$ & $\begin{array}{r}7,577 \\
6,609 \\
9,390 \\
10,876\end{array}$ & $\begin{array}{l}3,895 \\
4,221 \\
2,752 \\
1,918\end{array}$ & $\begin{array}{r}162 \\
116 \\
120 \\
54 \\
\\
452\end{array}$ & $\begin{array}{l}4 \cdot 1 \\
2 \cdot 7 \\
4 \cdot 3 \\
2 \cdot 8\end{array}$ \\
\hline
\end{tabular}


pyloric stenosis requiring surgery and in the remainder it was transient and passed with medical treatment.

Results of gastric analysis were available in 213 patients and the results are presented in Table V.

\section{TABLE IV}

AGE AND SEX DISTRIBUTION OF MELAENA OR HAEMATEMESIS

\begin{tabular}{llll} 
Age in years Males Females Total & $\begin{array}{l}\text { Percentage of } \\
\text { Total }\end{array}$ \\
\hline
\end{tabular}

\begin{tabular}{lrrrr}
\hline Below 20 & 1 & 1 & 2 & 2 \\
$21-30$ & 43 & 2 & 45 & 47 \\
$31-40$ & 34 & 2 & 36 & 36 \\
$41-50$ & 14 & 0 & 14 & 14 \\
Above 50 & 4 & 0 & 4 & 4
\end{tabular}

TABLE V

GASTRIC ANALYSIS RESULTS IN 213 CASES (100 ml. OF 7\% ABSOLUTE ALCOHOL)

\begin{tabular}{lcc} 
Acid & No. of Patients & Percentage \\
\hline Free Hcl above $60 \mathrm{ml} . \mathrm{N} / 10 \%$ & 148 & $69 \cdot 5$ \\
Free Hcl between 20 and $60 \mathrm{ml}$. & 23 & 11 \\
N/10\% & 39 & 18.3 \\
Free Hcl below $20 \mathrm{ml} . \mathrm{N} / 10 \%$ & 3 & 1.5 \\
Achlorhydria & 213 &
\end{tabular}

\section{POPULATION SURVEY}

The results of the survey are presented in Tables VI and VII.

\section{INDUSTRIAL MORBIDITY RECORDS}

The number of railway employees who reported sick and remained absent with a diagnosis of peptic ulcer was studied for Lumding and Gauhati.
In 1960 , there were 87 sick certificates issued for duodenal ulcer at Lumding and 82 at Gauhati. Data as to what proportion were chronic sufferers are not available. For want of this data it is not possible to determine the mean annual incidence rate of ulcer which would have given a very useful index of industrial morbidity due to ulcer. However, these figures show that active peptic ulcer causes $1.31 \%$ sick absenteeism at Lumding and $1.08 \%$ at Gauhati in adult male and female railway workers annually.

\section{DISCUSSION}

Previous work on peptic ulcer done in India had given rise to a belief that the disease was very common in south India and not so elsewhere (Somervell and Orr, 1936; Dogra, 1940; Hadley, 1959).

The disease was also believed to be different from the disease in the West in being less acute and the ulcer less likely to bleed or perforate. (Somervell and Orr, 1936; Raghvachari, 1959).

The present study has shown a high incidence of the disease in the railway workers in Assam, most of whom were rice-eating Bengalees, Biharies, or Assamese, there being no wheat-eating north Indians amongst them.

The incidence of active and passive ulcer in the adult population was $8.8 \%$ in office workers and $15.1 \%$ in manual workers. These figures are comparable to the figures found by Doll, Avery Jones, and Buckatzsch (1951) in their notable London survey. The observation made in other Indian studies that ulcer as it occurs in India is less likely to bleed and perforate also does not apply to the disease in Assam.

We first thought that our high figures might have

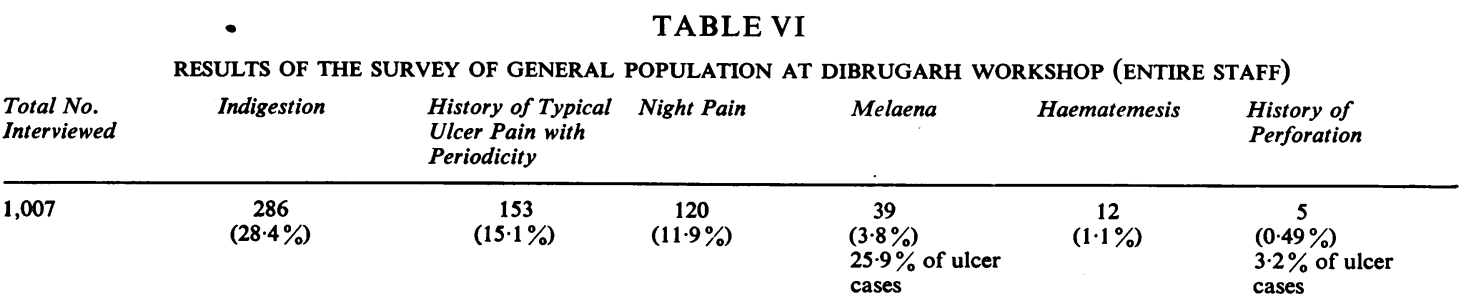

TABLE VII

RESULTS OF SURVEY OF GENERAL POPULATION AT HEADQUARTERS OFFICE INCLUDING CLERICAL STAFF ${ }^{1}$

\begin{tabular}{|c|c|c|c|c|}
\hline Total No. Interviewed & $\begin{array}{l}\text { Total with History of Ulcer } \\
\text { Pain and Periodicity }\end{array}$ & Indigestion and Acidity & History of Melaena & $\begin{array}{l}\text { History of Perforation during } \\
\text { Year under Study }\end{array}$ \\
\hline
\end{tabular}

\begin{tabular}{|c|c|c|c|c|}
\hline 1,009 & $\begin{array}{c}89 \\
(8.8 \%)\end{array}$ & $\begin{array}{c}47 \\
(4 \cdot 6 \%)\end{array}$ & $\begin{array}{l}17 \\
(1.5 \%) \\
19.9 \% \text { of ulcer } \\
\text { cases }\end{array}$ & $\begin{array}{l}1 \\
(0.1 \%) \\
1 \cdot 1 \% \text { of ulcer } \\
\text { cases }\end{array}$ \\
\hline
\end{tabular}

'Only staff at work were included, absentees being excluded. 
been due to selection playing a part, as with limited hospital accommodation only seriously ill patients with complications would be admitted. But the high incidence of haemorrhage is confirmed also by our survey studies, complications being present in $19.1 \%$ of the patients in Gauhati and $25.5 \%$ in the Dibrugarh group. The variation as related to occupation is also interesting, the complication being more common in office workers than in manual workers. As a further check we made a special study of this complication by specifically looking for it in our 1961 admissions at the Gauhati Hospital. Out of the 43 ulcer patients admitted to this hospital in 1961, $24(51 \cdot 1 \%)$ gave a history of melaena at some time or other; in $10(23.2 \%)$ melaena was the presenting symptom on admission. Garrido-Klinge and Pena (1959) have reported an even higher incidence (75\%) in their Peruvian study. In this respect, therefore, the ulcer in Assam differs from the ulcer in south India as reported by Somervell and Orr (1936). One of us (S.L.M.) has studied the ulcer problem in Udaipur (Rajasthan) and was impressed with this difference there too. The ulcer in Udaipur did not have the same tendency to bleed as did the disease in Assam.

Perforation was found to be extremely infrequent in the series of Somervell and Orr (1936). They came across four cases of perforation in a series of 2,500 cases of peptic ulcer, an incidence of $0.16 \%$ only. As compared to this, the incidence of perforation encount- ered in this study is very high, 8 to $14 \%$ of peptic ulcer admissions being for perforation. The annual incidence at Lumding where the railway patients must all come to the railway hospital, there being no other hospital there, works out at $24 \cdot 2$ per 100,000 of the population, $14 \%$ of the hospitalized ulcer patients and a little fewer than $2 \%$ of the active ulcer patients. One must, therefore, conclude that the ulcer as seen in Assam is not very different from the ulcer seen in the West, but it differs from the ulcer seen in the south of India.

Our experience of gastric acidity has also been different from that of other Indian workers, notably, Raghvachari (1959) who found that out of his series of 622 patients less than $10 \%$ showed hyperacidity.

\section{REFERENCES}

Dogra, J. R. (1940). Studies on peptic ulcer in South India. I: Introduction and clinical study of 258 cases. Ind. J. med. Res., 28 , 145-161.

Doll, R., Jones, F. A., and Buckatzsch. N. M. (1951). Occupational factors in the aetiology of gastric and duodenal ulcers. Spec. Rep. Ser. med. Coun. (Lond.), no. 276.

Garrido-Klinge, G., and Pena, L. (1959). The gastroduodenal ulcer in high altitudes (Peruvian Andes). In Proc. World Congress of Gastroenterology, 1958, pp. 68-78. Williams and Wilkins, Baltimore, Washington.

Hadley, G. G. (1959). Studies of peptic ulcer as found in South India. Ind. Coun. med. Res. Rep., no. 39, 31-33.

Raghvachari, C. (1959). Note on peptic ulcer. Ibid., no. 39, 48-51.

Somervell, T. H., and Orr, L. M. (1936). Some contributions to the causation, pathology, and treatment of duodenal ulcer and its complications. Brit. J. Surg., 24, 227-245. 